OPEN ACCESS

Edited by: Kazim Sahin

Firat University, Turkey

Reviewed by:

Lila Oyama,

Federal University of São Paulo, Brazil

Sharon Ross,

National Cancer Institute (NCl),

United States

${ }^{*}$ Correspondence:

Robert Weissert

robert.weissert@ukr.de;

robert.weissert@googlemail.com

Specialty section:

This article was submitted to

Clinical Nutrition,

a section of the journal

Frontiers in Nutrition

Received: 05 October 2018 Accepted: 10 December 2018 Published: 21 December 2018

Citation:

Herden $L$ and Weissert $R$ (2018) The Impact of Coffee and Caffeine on Multiple Sclerosis Compared to Other Neurodegenerative Diseases.

Front. Nutr. 5:133.

doi: 10.3389/fnut.2018.00133

\section{The Impact of Coffee and Caffeine on Multiple Sclerosis Compared to Other Neurodegenerative Diseases}

\author{
Lena Herden and Robert Weissert* \\ Department of Neurology, University of Regensburg, Regensburg, Germany
}

Background: The literature concerning the effect of coffee and caffeine on Multiple Sclerosis (MS) with focus on fatigue is investigated in this review. Potentially clinically relevant effects were also assessed in studies concerning comparable neurodegenerative diseases, such as Parkinson's disease (PD) and amyotrophic lateral sclerosis (ALS). Since the existing studies obtained very inconclusive results, we systematically reviewed these studies to summarize the evidence on the possible effects of coffee and caffeine on those disease entities. Previous studies suggested that coffee and caffeine intake is associated with a reduced risk of developing MS and other neurological diseases.

Methods: The PubMed database was searched using the keywords "coffee" OR "caffeine" in combination with keywords for each of the different diseases. Besides the keyword search, we included studies by reference list search. Studies on the effects of coffee and caffeine on the single neurological diseases were included for this review. A total of 51 articles met our inclusion criteria. The reviewed articles assessed the impact of coffee and caffeine on the susceptibility for neurological diseases, as well as the effect of coffee and caffeine on disease progression and possible symptomatic effects like on performance enhancement.

Results: Higher intake of coffee and caffeine was associated with a lower risk of developing PD. In some of the MS studies there, is evidence for a similar effect and experimental studies confirmed the positive impact. Interestingly in MS coffee and caffeine may have a stronger impact on disease course compared to effects on disease susceptibility. In ALS no such beneficial effect could be observed in the clinical and experimental studies.

Conclusion: This literature assessment revealed that coffee and especially caffeine could have a preventative role in the development of several neurodegenerative diseases if provided in comparatively high doses. The systematic assessment indicates that coffee and caffeine intake must not be considered as a health risk. Additional clinical studies are needed to fully understand how far coffee and caffeine intake should be considered as a potential therapeutic approach for certain disease entities and conditions.

Keywords: neuroinflammation, coffee, caffeine, adenosine, multiple sclerosis, Parkinson's disease, amyotrophic lateral sclerosis, neuroprotection 


\section{INTRODUCTION}

\section{Multiple Sclerosis}

Multiple Sclerosis (MS) is a chronic autoimmune disease of the central nervous system (CNS) that can affect individuals in all ages. Worldwide an estimated amount of 2.5 million people suffers from MS. It is assumed that $\mathrm{T}$ cells specifically identify and attack components of myelin sheaths in the CNS. The cause of MS has not been discovered yet, but it has been reported that genetic, as well as environmental factors contribute to its precipitation $(1,2)$. In how far those factors act in combination is presently investigated in different laboratories. MS leads to inflammation and demyelination, causing lesions in the white and gray matter. The resulting conductance reduction or/and block, axonal damage, and loss of neurons are responsible for the symptoms in MS. Such symptoms include numbness, vision disturbances, brain stem symptoms, bladder dysfunction, paresis, ataxia, and a slowly developing cognitive disability, depending on where the lesions are located.

\section{MS Disease Course and Fatigue}

MS is a disease with various disease courses. The majority of the patients first develop a relapsing-remitting type of MS (RRMS) which can transform into a secondary chronic progressive type (SPMS) over time (3). About 15\% of patients develop a primary progressive MS (PPMS).

There are also non-physical symptoms with fatigue the most relevant. Fatigue is an extreme exhaustion that overcomes patients without premonition. There exist various definitions for fatigue, most important is the fact that sleepiness and fatigue do not have the same meaning (4). In 2007 a group of neurologists closely investigated fatigue on patients with MS to finally set one definition as standard. They conclude, that "fatigue is defined, as reversible, motor, and cognitive impairment with reduced motivation and desire to rest, either appearing spontaneously or brought on by mental or physical activity, humidity, acute infection, and food ingestion. It is relieved by daytime sleep or rest without sleep. It can occur at any time but is usually worse in the afternoon. In MS, fatigue can be daily, has usually been present for years and has greater severity than any premorbid fatigue" (5). Fatigue is more than just the feeling of being tired. Patients suffering from fatigue often cannot manage a normal day without taking breaks. Especially fatigue has a strong impact on the working capacity of patients (4). More than $70 \%$ of the patients with MS are reporting about symptoms of fatigue (6). Studies have shown that $14 \%$ of patients with MS consider fatigue their worst problem and 55\% as one of their worst problems (7). It is also one of the main reasons for unemployment and early retirement (8-10). Patients with multiple sclerosis-related fatigue (MSRF) have a significantly increased mental and physical disability and a lower quality of life (11).

\footnotetext{
Abbreviations: AD, Alzheimer's disease; ALS, amyotrophic lateral sclerosis; cAMP, cyclic adenosine monophosphate; CNS, central nervous system; EAE, experimental autoimmune encephalomyelitis; EDSS, expanded disability status scale; GABA, gamma-aminobutyric acid; MS, multiple sclerosis; OR, Odd's ratio; PD, Parkinson's disease; PDE, phosphodiesterase; PKA, protein kinase A.
}

Although fatigue is such a profound symptom, the mechanisms behind its onset have not been identified yet. A recent study showed that there is possibly a correlation between fatigue and structural damage in the brain (12). Currently, there is no approved medical therapy for fatigue available. Several substances have been evaluated regarding its influence on fatigue. Even meta-analysis about various pharmacological therapies could not give evidence for an effective treatment (13). There exist single studies indicating that modafinil (14) and amantadine (15) might have a positive effect on the condition of patients, but in further meta-analysis no significant impact could be demonstrated. Due to missing comparative studies between several therapeutic approaches, there still exists no first-line therapy for fatigue.

A recent meta-analysis has shown that psychological interventions, like cognitive behavioral therapy, relaxation exercises, and mindfulness interventions could significantly reduce fatigue levels (16). Thus, at trying to treat fatigue, currently, it is most important to inform patients about fatigue. It is advised to ask for sleeping disorders, to check the current medications for tiring side effects, and explain the value of sports and physical activity during the day for preventing or tempering fatigue $(13,17)$. However, the treatment options are still limited.

Since coffee and caffeine showed a beneficial effect on daytime somnolence in Parkinson's disease (PD) (18) a comparable positive effect in MS might be assumed. The effects of coffee and caffeine on MS-related fatigue have not been investigated yet. Still few studies exist that assessed the effect of coffee and caffeine on disease susceptibility and course.

Therefore, in this review we focused on summarizing the possible effects of coffee and caffeine in MS. Since literature cannot present enough data to provide a clear statement, we also reviewed studies concerning its effects on PD and ALS with the intention to obtain an overview and a better understanding of how coffee and caffeine might act in the CNS.

\section{Coffee}

\section{The History of Coffee and Caffeine as a Medical Treatment}

The use of caffeine as a medical treatment started off slowly in the early nineteenth century, when 1,819 the German chemist Friedlieb Ferdinand Runge isolated caffeine for the first time. Half a century later, in 1886 the first version of caffeine containing Coca-Cola was sold as a patent medicine for headache (19). Thereafter the interest in medical effects of caffeine and coffee consumption has increased rapidly.

Even if coffee was introduced in Europe only a few 100 years ago (Box 1), it has reached an important position in our culture. By now coffee is one of the most popular beverages all over the world. Not just because of its taste, particularly the caffeine content leads to its enormous popularity. In the last years, the way of consuming coffee has experienced a massive transformation. Especially the popularity in younger adults has risen in the last decades. People go to coffee shops to have a coffee every day, meeting friends, taking a break or just enjoy a cup of cappuccino. Most people from all cultures consume coffee frequently if not daily. 
BOX 1 | The history of coffee (20-23).

The knowledge about coffee, in the way we consume it presumably developed in the $15^{\text {th }}$ century in the region of Yemen. Earlier references appeared only in legends, suggesting a $9^{\text {th }}$ century origin in Ethiopia and Yemen. Interestingly, at that time the green coffee beans were just eaten raw. In the $16^{\text {th }}$ century, the coffee bean spread to the Middle East, South India, Persia, Turkey, and Northern Africa and has found its way into Europe via Italy. The former Republic of Venice kept a vibrant trade with Muslims from Northern Africa. In the early $17^{\text {th }}$ century coffee appeared in Venice, in which a short time after the first European coffee house opened. Once in Europe, coffee gained increasingly in popularity and spread so fast, that in 1652 the first London coffee house opened.

TABLE 1 | Average chemical composition of coffee Arabica beans in \% of the dry matter, before, and after roasting (24-31).

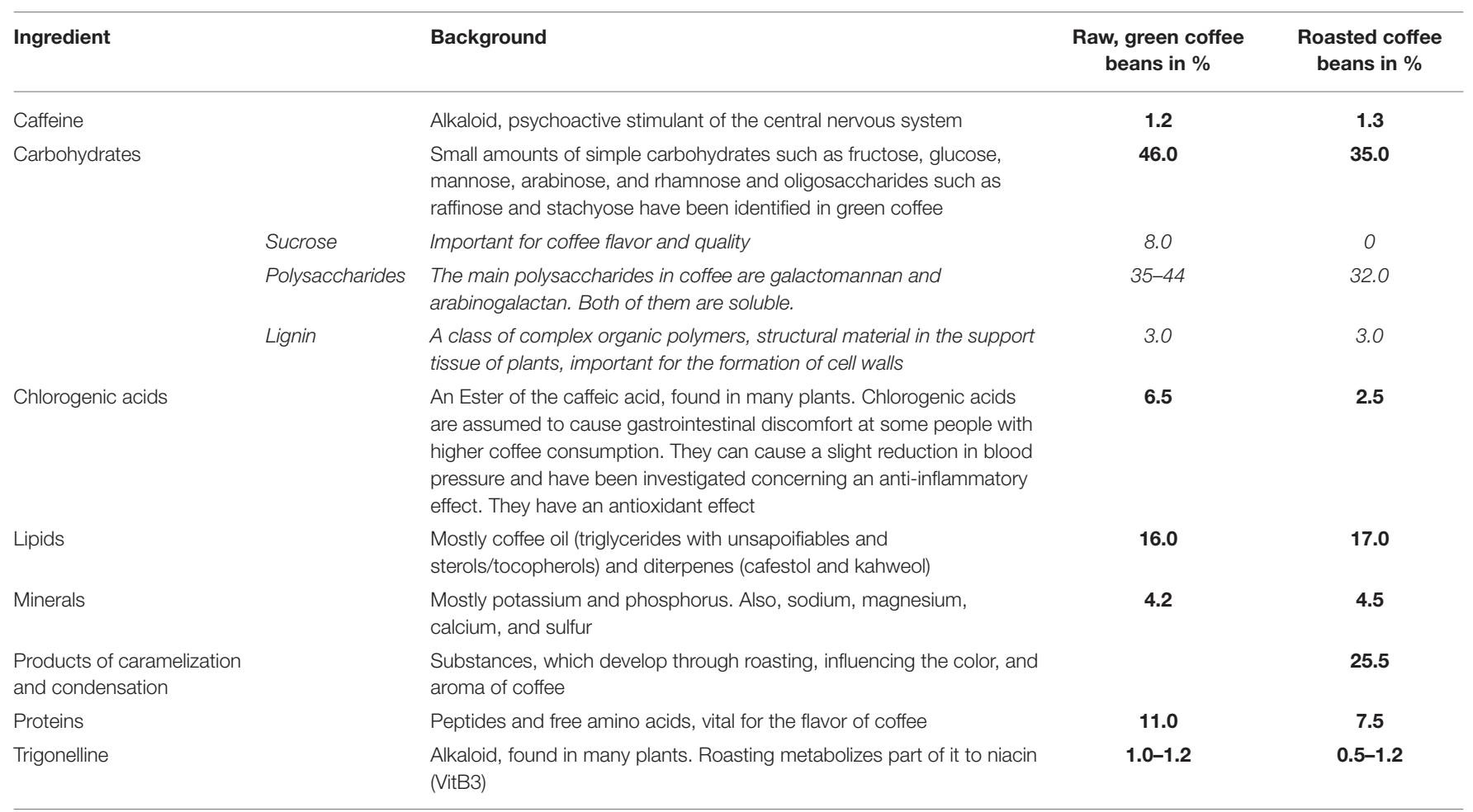

\section{Composition}

Coffee consists of more than 1,000 ingredients (Table 1), including carbohydrates, lipids, vitamins, minerals, and alkaloids (32), depending on the variety and the further processing. Coffee is one of the most important sources of chlorogenic acids (33). There have been studies, showing the antioxidative effect of chlorogenic acids, and caffeic acids in vitro (34), yet there are no results showing this effect in vivo. This may be due to the massive metabolism of the acids in the human body. From all the ingredients, caffeine is the most investigated one. Its psychostimulant effect has been reported as well as its positive short-term effect on attention and mental condition like cognition and memory (35). Coffee is one of the most essential sources of caffeine, but also soft drinks and energy drinks cover up a significant part of the caffeine intake, especially for children (36) (Table 2).

\section{Pharmacokinetics}

The amount of caffeine in coffee varies among different sorts. It has been shown, that there are diverse effects on the CNS, comparing coffee Arabica to coffee Robusta (41). The caffeine contained in coffee is absorbed very fast compared to other sources (42). It is completely absorbed within $45 \mathrm{~min}$ after oral ingestion. It reaches its highest plasma concentration after 20$30 \mathrm{~min}$, and due to its hydrophobic structure, it can pass the blood-brain barrier (BBB) easily to have its full effect on the CNS $(43,44)$.

\section{Caffeine}

Caffeine (1, 3, 7-trimethylxanthine) belongs to the purines and its main effect is as a psychostimulant in the CNS. The stimulant effects of caffeine are due to its ability to decrease the transmission of adenosine in the various regions of the brain (45).

\section{Adenosine Receptors}

Adenosine, which structure is very similar to caffeine, is considered a neuromodulator. It plays a critical role in several biochemical processes, generally inhibiting excitability in the CNS through different pathways, activated by different types of adenosine receptors. There exist various types of adenosine receptors: $\mathrm{A} 1, \mathrm{~A} 2 \mathrm{a}, \mathrm{A} 2 \mathrm{~b}$, and $\mathrm{A} 3$. They can be 
TABLE 2 | Beverages containing caffeine with data about caffeine content $(37-40)$.

\begin{tabular}{|c|c|c|c|}
\hline & $\begin{array}{l}\text { Caffeine per } \\
100 \mathrm{ml}[\mathrm{mg}]\end{array}$ & $\begin{array}{c}\text { Serving } \\
\text { size }[\mathrm{ml}]\end{array}$ & $\begin{array}{l}\text { Caffeine per } \\
\text { serving [mg] }\end{array}$ \\
\hline Brewed coffee & $60-100$ & 150 & $90-150$ \\
\hline Espresso & $100-150$ & 30 & $30-50$ \\
\hline Instant Coffee & $27-72$ & 150 & $40-108$ \\
\hline Decaffeinated & $1-3$ & 150 & $2-5$ \\
\hline Tea & $6-22$ & 250 & $15-55$ \\
\hline Iced tea & $6-10$ & 250 & $15-25$ \\
\hline Coca cola & 10 & 250 & 25 \\
\hline Diet coke & 13 & 250 & 33 \\
\hline Decaffeinated coke & 0 & 250 & 0 \\
\hline Energy drinks monster & 34 & 250 & 85 \\
\hline Red bull & 34 & 250 & 85 \\
\hline Energy Shots e.g., 5-h-energy & 333 & 60 & 200 \\
\hline Chocolate Milk beverage & $1-3$ & 250 & $2-7$ \\
\hline
\end{tabular}

found in different cells in the CNS, such as astrocytes, microglia, and neuronal cells of the striatum, and the spinal cord. Also in immune cells and endothelial cells adenosine receptors are expressed (46). Caffeine stimulates the CNS, as well as improves cognitive function, reaction time, wakefulness, concentration, and motor coordination (47).

The binding of adenosine to A1 and A3 receptors lead to inhibition of the adenylyl cyclase through activation of the inhibitory G-protein. Thus, less cyclic AMP (cAMP) is available, causing a reduced activation of the protein kinase $A$ (PKA). The inactivated PKA causes a reduced flow of calcium into the cell. In contrary, when adenosine binds to $\mathrm{A} 2 \mathrm{a}$ or $\mathrm{A} 2 \mathrm{~b}$ receptors it activates a stimulatory G-protein inducing the opposite effects leading to an increase of intracellular calcium (48).

Caffeine acts as an antagonist on adenosine receptors. At $300 \mathrm{mg}$ of intake (which is equivalent to $2-3$ cups $[150 \mathrm{ml}$ each] of coffee), it has its highest affinity for A1 and A2a receptors (49). The A1, as well as the A2a receptors, are both $\mathrm{G}$-protein-coupled but lead to opposite effects. When adenosine is binding to $\mathrm{A} 2 \mathrm{~b}$ receptors in cells in which the $\mathrm{A} 1$ receptor is also expressed, it inhibits A1 receptors to bind adenosine and increases calcium influx (50). The A1 receptor can be found all over the CNS, whereas A2a receptors were found concentrated in dopamine rich areas of the brain $(51,52)$. The blocking of these receptors downregulates the release of dopamine, noradrenaline, and glutamate (53). Solely blocking of the A2a receptor reduces direct calcium entry into neurons and decreases inflammatory reactivity of microglia (54). Glutamate is a neurotransmitter which causes cytosolic calcium release leading to a more severe inflammatory response $(55,56)$. Upregulation of A1 receptors has an inverse effect on the production of pro-inflammatory cytokines, in particular, tumor necrosis factor alpha (TNF- $\alpha$ ) (57). In conclusion, caffeine leads to an anti-inflammatory effect, mainly via the antagonism of the $\mathrm{A} 2 \mathrm{~b}$ receptor and there is also evidence that the A1 receptor might contribute to this effect.

\section{Further Actions in the Brain}

The total of the effects of caffeine on the cellular level is incompletely understood. It modifies the synaptic and ectopic vesicle release (58). Moreover, it interferes with GABA-A receptors (59). The upregulation of GABA receptors is due to the decrease of GABA concentration induced by caffeine. GABA normally modulates our sensation of alertness and tiredness and helps us relax. In the situation of reduced GABA concentrations in the CNS, the body feels more active, and the motor activity is higher. Additionally, it leads to a non-selective competitive inhibition of phosphodiesterase (PDE) and an activation of the ryanodine receptor (60). Inhibitors of the PDE simultaneously inhibit the inactivation of second messengers, like cAMP. Due to this, the amplification of intracellular signals through second messenger is extended. Because of the activation of ryanodine receptors, a calcium releasing channel on the endoplasmic reticulum (ER), caffeine and especially its metabolite paraxanthine can induce calcium release from the sarcoplasmic reticulum and inhibit its reuptake (61). Caffeine can reduce cerebral blood flow (62). However, some of the described effects on cellular function could only be observed in vitro. In vivo, much higher levels of caffeine are required $(36,63)$. The plasma concentrations required to have such effects in humans cannot be reached by coffee intake (43).

All the therapeutic and adverse effects differ immensely depending on whether the long-term or acute effect of coffee consumption is considered. Chronic caffeine administration may be responsible for the possible neuroprotective effect of caffeine, due to its increased adenosine plasma concentration (64). Whereas, the acute effects of caffeine intake lead to the well-known psychic activation.

\section{Actions of Caffeine on the Body}

In addition to the above described effects on the CNS, caffeine does have effects on the whole body. Caffeine leads to a bronchodilation, a peripheral vasodilation, and due to its positive inotropic effect increases the contractility and efficiency of the heart (61). It stimulates digestion by promoting peristalsis and has diuretic effects on kidney (65). Consequently, in the last years, the consumption of coffee has been discussed controversially. It is known that caffeine (i.e., $150 \mathrm{ml}$ coffee/cup) consumption has short-term effects on blood pressure in individuals with normotensive or hypertensive pressure (66). Regardless, studies examining the long-term effects on blood pressure in habitual coffee drinkers did not yield significant results (67). A recent meta-analysis did not demonstrate clinical evidence for effects of long-term coffee consumption on blood pressure (68). Additional studies as well did not show evidence of health risks mediated by caffeine but found evidence of potential benefits. Taken together the results indicate that a coffee consumption of up to four cups of coffee per day can be considered completely healthy (69). In some of those studies, an association between high coffee intake and an unhealthy lifestyle was assumed, including behaviors like smoking or less physical activity which may have caused the wrong assumptions (67). 


\section{METHODS}

This systematic review was performed in accordance with the guideline of the Preferred Reporting Items for Systematic Reviews and Meta-Analysis (PRISMA) statement (70).

\section{Literature Research}

Studies were identified by searching the PubMed database and scanning reference lists of articles. Database searches were conducted between 15th of May 2018 and the 18th of June 2018 by both authors separately. The first literature search was done by LH and for revision by RW. There was no date or language restriction in the search strategy. For the studies concerning MS we searched by the terms "coffee" "OR" "caffeine" "AND" "multiple sclerosis." We obtained 38 articles and after scanning the abstract we selected six studies meeting the criteria for this review. We repeated this for the studies concerning ALS, and by searching for "coffee" "OR" "caffeine" "AND" "amyotrophic lateral sclerosis" "OR" "ALS." We obtained 33 articles, of which only four met our review criteria. For studies concerning PD, we used the terms "coffee" "AND" "Parkinson"” and obtained 219 articles. We included 34 of those for our review. Additionally, we included seven articles which we found by scanning reference lists, leading to a total of $41 \mathrm{PD}$ studies.

\section{Study Selection}

Due to few existing studies, we included prospective and retrospective clinical and epidemiological studies as well as animal and in vitro studies that dealt with the possible mechanisms of action. Therefore, we categorized the studies by study design for the revision.

In total 281 articles were obtained from the PubMed database search. For MS 38 articles were obtained by database search. 25 of those were excluded because they also did not investigate the effect of coffee or caffeine or/and did not deal with MS. Three articles were excluded for not presenting all data of the study or reviewing other studies insufficiently. There was no full-text available for four articles. Therefore, the six remaining studies were included for the review. The 210 articles obtained for PD were reviewed. One hundred and forty three articles did not meet our inclusion criteria because they did not investigate PD or/and did not investigate the effect of coffee or caffeine. Another 16 articles were excluded because of not meeting high quality, like just reviewing existing studies or reviewing articles which did not present any outcome data. Lastly, 17 articles were rejected because no full text was provided. Through the 34 included studies we obtained seven additional articles by scanning the reference lists, which resulted in a total of 41 included articles. Equally, the 33 articles on ALS obtained by database search were examined. Twenty six of the search results were articles, which again did not investigate either the effect of coffee or caffeine, or the effect on ALS. One article reviewed literature and for two articles no full-text was provided. In total, four articles on ALS were included. A flowchart about the research strategy was created (Supplementary Figure 1). The total of 51 selected studies are summarized in Table 3 and Supplementary Tables 1-3.

\section{Data Extraction}

The data extracted from the eligible studies included: authors, year, and country of publication, study design (type of intervention and main aim of the study as the primary outcome), intervention details (like doses of coffee or caffeine), duration (if given also time of follow-up period), population (sample size, mean age, gender distribution-if mentioned in the article), and the findings of the single studies.

\section{RESULTS}

\section{Coffee and MS}

The six studies regarding MS and coffee or caffeine effects that fitted the inclusion criteria for detailed evaluation in this review, showed a high heterogeneity in their designs (Table 3). The limited number of studies assessing the effect of coffee or caffeine on MS did not allow performing a meaningful meta-analysis. Still some conclusions can be drawn.

Two matched case-control studies $(n=210$ and $n=282)$ of the total of four studies, which assessed an effect on MS susceptibility, could demonstrate an increased intake of coffee in patients with MS, compared to the healthy controls $(73,75)$. Still, both studies could not determine coffee as a significant risk factor for MS, due to their very inconclusive findings.

Another study found no significant association between coffee and the risk for MS, neither positive nor negative (72). Two hundred and eighty two cases of MS out of a total of $n=187,326$ women were found. A more recent comparison of two studies from 2015 (in total $n=2,779$ cases and $n=3,960$ controls) observed a significant association between high consumption of coffee ( $>900 \mathrm{ml}$ daily) and a decreased risk for MS (OR 0.70, $p=0.01$ and $\mathrm{OR} 0.69$ and $p=0.05$ in the individual studies) (71).

A cross-sectional survey from $2011(n=1,372)$ showed that coffee consumption does have a positive effect on the disease course and progression, at least in the relapsing form of MS (74). The authors set the time for reaching EDSS (Expanded Disability Status Scale) step 6 as an outcome measure and compared groups with different intake levels of coffee. They discovered a significant extension of that time by 4 years comparing the daily coffee drinkers to the never coffee drinkers $(p=0.002)$.

An experimental study was performed in 2009 to evaluate if chronic caffeine treatment has any neuroprotective effects on the course of an animal model of MS, namely experimental autoimmune encephalomyelitis (EAE) in rats (76). The used EAE model is characterized by extensive tissue inflammation and a chronic disease course. The incidence of EAE decreased within the caffeine treated rats $(n=126)$ and an attenuation of the disease on behavioral, neurochemical, and histological levels $(p<0.005$ compared to rats, who received only water) was demonstrated.

\section{Coffee and Amyotrophic Lateral Sclerosis}

Amyotrophic lateral sclerosis (ALS) is an incurable disease characterized by progressive degeneration of motor neurons in spinal cord and motor cortex (77). Only a few studies have investigated the relationship between coffee or caffeine and the effects on patients with ALS (Supplementary Table 1). 
TABLE 3 | Studies evaluating the effect of coffee on multiple Sclerosis and EAE.

\begin{tabular}{|c|c|c|c|c|}
\hline & References & Study design & Cases & Findings \\
\hline \multirow[t]{5}{*}{$\begin{array}{l}\text { Clinical } \\
\text { trial }\end{array}$} & $\begin{array}{l}\text { Hedström et al. } \\
\text { (Sweden, US) (71) }\end{array}$ & $\begin{array}{l}\text { Comparison of two population } \\
\text { representative case-control studies } \\
\text { based on retrospective data collection }\end{array}$ & $\begin{array}{l}1,620 \text { cases and } 2,788 \text { controls } \\
\text { in the Swedish study and } 1,159 \\
\text { cases and } 1,172 \text { controls in the } \\
\text { US study } \\
\text { Age } 16-70\end{array}$ & $\begin{array}{l}\text { The risk of MS is substantially reduced among those } \\
\text { who reported a high consumption of coffee, } \\
\text { exceeding } 900 \mathrm{ml} \text { daily OR } 0.70 \text { ( } 95 \% \mathrm{Cl} 0.49-0.99 \\
\text { in the Swedish study) and OR } 0.69 \text { ( } 95 \% \mathrm{Cl} \\
0.5-0.96 \text { in the US study). }\end{array}$ \\
\hline & Massa et al. (US) (72) & $\begin{array}{l}\text { Statistical analysis, concerning the } \\
\text { intake of alcohol and caffeine were } \\
\text { examined in relation to the risk of MS } \\
\text { in two large cohorts of women }\end{array}$ & $\begin{array}{l}\text { Nurses' Health study (NHS) } \\
92.275 \text { women followed for } 24 \\
\text { years and NHSIl 95,051 women } \\
\text { followed for } 14 \text { years } \\
282 \text { MS cases during the follow } \\
\text { up } \\
\text { Age } 30-55 \text { and } 25-42\end{array}$ & $\begin{array}{l}\text { No significant association was found between } \\
\text { coffee or caffeine intake and the risk of MS. The } \\
\text { evaluation of caffeinated coffee vs. decaffeinated } \\
\text { coffee also yielded no results. }\end{array}$ \\
\hline & $\begin{array}{l}\text { Ponsonby et al. } \\
\text { (Australia) (73) }\end{array}$ & $\begin{array}{l}\text { Case-control study assessed life-style } \\
\text { factors, like smoking alcohol or coffee } \\
\text { intake and physical activity, prior to a } \\
\text { first clinical demyelinating event }\end{array}$ & $\begin{array}{l}\text { Cases } n=282, \\
\text { Controls without CNS } \\
\text { Demyelination } n=558, \text { matched } \\
\text { in age and sex and study region } \\
\text { Age } 18-59\end{array}$ & $\begin{array}{l}\text { No significant results concerning an effect of coffee } \\
\text { could be shown. Still the case groups were much } \\
\text { more likely to a coffee intake of five or more } \\
\text { cups/day in the last year. }\end{array}$ \\
\hline & $\begin{array}{l}\text { D'hooghe et al. } \\
\text { (Belgium, the } \\
\text { Netherlands) (74) }\end{array}$ & $\begin{array}{l}\text { Cross sectional survey amongst } \\
\text { individuals with MS, with time to } \\
\text { EDSS } 6 \text { as outcome measure }\end{array}$ & $\begin{array}{l}1,372 \text { persons with definite MS } \\
\text { were analyzed } \\
\text { Age } 17-89\end{array}$ & $\begin{array}{l}\text { An extension by } 4 \text { years for the time to reach EDSS } \\
6 \text { since birth was demonstrated in the group with } \\
\text { daily coffee intake, compared to the group with } \\
\text { individuals who never drank coffee }(p=0.002)\end{array}$ \\
\hline & $\begin{array}{l}\text { Pekmezovic et al. } \\
\text { (Serbia) (75) }\end{array}$ & $\begin{array}{l}\text { Case control study evaluating } \\
\text { association between the risk of MS } \\
\text { and lifestyle factors like cigarette } \\
\text { smoking and coffee, and alcohol } \\
\text { consumption }\end{array}$ & $\begin{array}{l}n=210 \text { cases with definite MS, } \\
n=210 \text { controls, matched in } \\
\text { age and sex } \\
\text { Mean Age } 33,6 \pm 10,2\end{array}$ & $\begin{array}{l}\text { Coffee consumption was significantly more frequent } \\
\text { in the MS-group but was not considered a risk } \\
\text { factor. A dose-response relationship was shown } \\
\text { between risk of MS and both, number of cups/day } \\
(p=0.039) \text { and duration of coffee intake in years } \\
(p=0.01)\end{array}$ \\
\hline $\begin{array}{l}\text { Animal } \\
\text { Model }\end{array}$ & Chen et al. (China) (76) & $\begin{array}{l}\text { The attenuation of guinea pig spinal } \\
\text { cord homogenate induced pathology } \\
\text { by chronic caffeine treatment was } \\
\text { observed at doses of } 10 \text { and } 30 \\
\mathrm{mg} / \mathrm{kg} \text { and during both peak and } \\
\text { recovery phases of EAE }\end{array}$ & $\begin{array}{l}126 \text { females, EAE induced } \\
\text { Wistar rats }\end{array}$ & $\begin{array}{l}\text { Caffeine decreases the incidence of EAE and } \\
\text { attenuates EAE pathology at behavioral, histological, } \\
\text { and neurochemical levels. } \\
\text { Chronic treatment with caffeine up-regulated A1 } \\
\text { receptor and TGF- } \beta \text { mRNAs and suppressed } \\
\text { interferon- } \gamma \text { mRNA in EAE }\end{array}$ \\
\hline
\end{tabular}

While a recent meta-analysis of five large cohort studies (total $n=1,010,000$ with $n=1,279$ cases of ALS) has not found any association between coffee intake and the risk of ALS (78), a prior case-control study ( $n=377$ cases and $n=754$ controls) did find an inverse effect of coffee consumption and the risk of ALS (79). The authors compared the ALS cases to neurological and nonneurological hospital controls. They reported a lower risk for ALS among ever coffee drinkers (intake $>1$ cup/day for at least 6 months during lifetime), compared with never coffee drinkers $(O R=0.6,95 \% C I=0.4-0.8)$.

A preceding prospective study from 2008 (80) assessed the effect of various dietary habits on ALS and found no significant association between caffeinated coffee and the risk of developing ALS. Interestingly the authors observed a significant relationship between a high intake of decaffeinated coffee ( $\geq 4$ cups/day) and the risk of ALS $(p=0.01)$.

There exist only one experimental study which examined the presumed neuroprotective effect of chronic caffeine administration in an animal model of ALS (81). In a transgenic model of ALS, SOD1(G93A) mice (SOD, superoxide dismutase 1) that received caffeine compared to controls receiving water had lower body weight, reduced motor performance, earlier disease onset, and reduced survival times. Specifically, caffeine treatment accelerated disease progression and shortened survival time by an average of 12 days $(p=0.01)$.

\section{Coffee and Parkinson's Disease}

The association between coffee and caffeine and a reduced risk of developing $\mathrm{PD}$ has been investigated in the last 50 years. Although the existing studies differ in their results, there is evidence for possible neuroprotective effects of caffeine in PD. The combined relative risk in a recent meta-analysis was 0.67 (95\% CI 0.58, 0.76) (82). Therefore, we reviewed the published studies $(n=40)$ from 1968 until today (Supplementary Tables 2, 3).

Five of the studies evaluated the effect of coffee on the progression or the symptomatic enhancement of PD (18, 83-86). Results were contradictory but for some evaluated symptoms, coffee showed a beneficial effect. Caffeine improved the "total akinesia" type of freezing of gait (FOG) in PD. A prospective study $(n=16)$ from 2007 could demonstrate an improvement of the total akinesia for a certain time period. Interestingly the beneficial effect disappeared after a few months, although the effect could be completely restored after a 2-week caffeine withdrawal (86). 
An analysis, evaluating the data of two studies (total $n=413 \mathrm{PD}$ cases) concerning the rate of progression and the influence of caffeine could not find any significant effects (85).

Two prospective placebo-controlled trials from $2012(n=61)$ and $2017(n=121)$ did not observe a strong beneficial effect of coffee concerning motor function. A small improvement by 4.7 points $(p<0.05)$ on Unified Parkinson's Disease Rating Scale (UPDRS) was seen $(83,84)$.

However, somnolence improved modestly in PD patients as seen by reduction of sleepiness documented with the Epworth Sleepiness Scale (ESS) (83). After a 6-week caffeine disposal, ESS was reduced by 1.71 compared to the placebo group. Still, this study provides evidence that a 6-week caffeine treatment does not improve daytime sleepiness significantly in patients with PD. In contrast a recent low-powered prospective study showed that espresso intake had a significant effect on daytime somnolence in PD (18).

The susceptibility of PD and the possible protective effects of coffee have been examined closely over the last decades. Nine prospective cohort studies were performed to evaluate the effect of coffee and caffeine (87-95). All of those found evidence for a significant beneficial effect of coffee consumption on the risk of developing PD.

The most recent prospective cohort study $(n=539,222$, participants were recruited from the Cancer Prevention Study II and filled-out a questionnaire about dietary habits) found an inverse association between coffee consumption and the risk of developing PD $(R R=0.43,95 \% C I=0.26-0.71, p \leq 0.002)$ for caffeine intake at $477 \mathrm{mg} /$ day ( $3-4$ cups a $150 \mathrm{ml}$ ) compared to a caffeine intake of $9,2 \mathrm{mg} /$ day in men (92). For women the effect was slightly smaller [RR 0.61 (95\% CI: $0.34-1.09$; $p=0.05)$ ]. Among women, the beneficial effect was stronger among never users of hormone replacement therapy $(R R=0.32)$ than among ever users $(R R=0.81, \mathrm{p}$-interaction $=0.15)$. Interestingly four of these nine studies found a stronger effect in men compared to women. Several studies came to the same result that women who had never taken postmenopausal estrogen do have an increased risk for developing PD when consuming coffee $(91,92)$.

Previous case-control studies (96-111) suggest that coffee consumption is inversely associated with the risk of PD.

Two case-control studies $(n=812$ and $n=1,208)$ investigated the genetic influence on how coffee can affect the risk of PD. No significant association between the ADORA2A, the CYP1A2 gene, and the effect of coffee on PD could be shown (98). The second study assessed the impact of coffee on PD patients with high genetic risk (LRRK2 R1628P variant) compared to those with lower genetic risk for PD. Caffeine intake significantly reduced the risk of $\mathrm{PD}$ much more in those patients with high genetic susceptibility (R1628P variant) compared to those with low genetic susceptibility. Patients with high genetic risk who did not take caffeine had 15 times higher risk of PD compared to patients with low genetic risk with caffeine intake. About $70 \%$ of this risk increase is due to the interaction of R1628P and no caffeine intake (96).
Retrospective evaluation showed a delay of PD onset by 4.8 years for participants who drank three or more cups of coffee daily (112).

$\mathrm{PD}$ is a disease mainly characterized by the reduction of the dopaminergic neurons of substantia nigra due to a neurodegenerative process (113). The experimental studies in animal models that have been reported so far support the role of adenosine receptor antagonists such as caffeine on PD.

The first study from 2001 demonstrated that caffeine in equivalent doses to human intake could attenuate the dopaminergic degeneration of anatomical and functional markers in the MPTP (1-methyl-4-phenyl-1,2,3,6tetrahydropyridine) experimental model in mice $(n=18)$. (114) MPTP is a neurotoxin, which can induce striatal dopaminergic depletion (115). The authors additionally discovered that A2a receptor-specific antagonists, in contrast to A1 receptorantagonists, could mimic the neuroprotective effects of caffeine. In 2006, after epidemiological studies in humans provided data of estrogens, which could attenuate the beneficial effect of caffeine in women, this finding was confirmed in the MPTP mouse model of PD $(n=22)$ (116).

In a similar model, the effect of a caffeine administration, $30 \mathrm{~min}$ prior to an eight-day MPTP treatment was evaluated (117). The caffeine-treated mice showed less neuronal damage, better paw grip strength, and motor function. In another model of $\mathrm{PD}$, caffeine had a comparable protective effect (118). In the used 6-OHDA (6-hydroxydopamine) model of PD in rats, the injection of OHDA in the brain parenchyma or ventricles leads to noradrenaline-, adrenaline-, and dopamine depletion $(n=72)$ (119). MPP+ (methyl-4-phenylpyridinium) is a neurotoxin, which is infused into one of the lateral ventricles of rats over a time course of 28 days ( $n=5$ per group) (56). The ensuing ipsilateral dopaminergic neuron loss could be prevented when caffeine was given before, as well as arrested when given in drinking water after the injection.

To investigate the in vitro cytoprotective mechanisms of caffeine, human dopaminergic neuroblastoma SH-SY5Y cells were used. Caffeine prevented apoptotic cell-death after serum/retinoic acid depletion, MPP+, rotenone, and 6-OHDA applications in a dose-dependent relationship. Additionally, it reduced an induced caspase-3 activity, which suggests that caffeine's protective effect is due to the activation of the phosphatidyl-inositol-3-kinase (PI3K)/Akt pathways (120). This pathway is not completely understood yet, nevertheless it is evident that it is involved in inhibition of neuronal apoptosis (121).

\section{DISCUSSION}

Caffeine as a non-selective antagonist of adenosine receptors with its neuroprotective effects as well as the general impact of coffee on chronic and autoimmune diseases have recently been investigated very closely. The precise mechanism underlying caffeine's neuroprotective effect has not been fully understood, yet a beneficial effect could be observed in various disease entities and conditions. 
The current state of knowledge permits the conclusion that coffee and caffeine intake in moderation must not be considered as a health risk. Since most people drink coffee for pleasure and because of its taste, a possible health benefit would be an added value.

The existing epidemiological studies lead to the conclusion, that coffee and especially caffeine could have a preventative role in the development of several neurodegenerative diseases. However, recent data in animal models suggest that caffeine may also have therapeutic effects on patients already diagnosed with a certain disease entity. Further clinical studies are needed to fully understand how and in how far coffee and caffeine intake should be regarded as a potential therapeutic approach.

The included studies did have limitations. Possibly in some of the studies, no generalized conclusion should be drawn because of the used inclusion criteria. For example in the Nurses' Health Study I and II only women at a quite similar age were included (72). Another limitation for our review is the situation that not all the assessed studies specified the exact amount of coffee or caffeine intake in the in investigated groups of patients. Some of the studies only counted the number of cups per day which may vary in size and dose. The single compliance in the different studies is mainly unclear, as well as in how far the subjectively stated amount of coffee intake can be trusted. Nevertheless, we tried to secure quality by only including original peer-reviewed articles.

With most of the studies assessing the influence of different dietary habits, it would be interesting to evaluate the effect of coffee or caffeine in isolation more closely. Examining several dietary habits at once raises the question, whether the other habits must be looked at as confounders and possibly must be considered in the results. It is not clear yet, in how far this may modify the results for the effect of coffee and caffeine intake. Additional studies, more specified on the effect of coffee and caffeine should rule out the possible effect of confounders.

At this point it should be mentioned, that coffee consumption should not be equated with caffeine intake. There are far more ingredients in a cup of coffee than just caffeine. Even if caffeine is the most investigated one, other contents have been observed to have a not insignificant effect on the body as well (Table 1). Attention should be given to the various contents and how they may work in combination. Additionally, the relaxing effect of taking a coffee break may play a more pronounced role than assumed. Coffee can be used for a more structured daily routine and the assessment of the psychological impact of a hot cup of coffee would be interesting for research. Regarding this, studies should aim to compare the effect of caffeine, e.g., as caffeine pills with the effect of the same amount of caffeine in coffee.

Interestingly this review revealed that caffeine may have beneficial effects in MS and PD but not in ALS. None of the epidemiological or experimental studies have found a positive impact of caffeine intake on susceptibility or disease course of ALS. In additional prospective clinical studies, it would be interesting to see, if an effect comparable to MS and PD can be found. In PD the results suggest a potential motor benefit. Larger long-term studies would be desirable. The studies in PD on the possible risk-reducing effect of coffee vary in their results and quality. Some of those examined a multitude of dietary habits at once that may interfere with the results. In most of those, a beneficial effect of coffee could only be observed in the groups with the highest amount of caffeine intake, which means up to 5 cups per day/a liter per day. The most significant outcomes were found in smaller studies that had a closer look at the coffee intake, including the duration of coffee consumption in years and the intake classified into many categories.

Coffee and caffeine may reduce the risk of some diseases significantly if contained in high doses what equals about six cups of coffee per day. It is still questionable if coffee intake up to almost a liter should be advised to everyone. Importantly, over usage of caffeine-containing beverages can lead to a mild physical dependence. Caffeine addiction cannot be set by certain amounts of coffee and caffeine intake. The addiction is described by the ICD10 F15.2 diagnosis: other stimulant dependence. Therefore, the same criteria, as in any other addiction must be fulfilled. A strong desire to take the substance, difficulties in controlling the intake, a physiological withdrawal state when substance use has ceased or has been reduced, evidence of tolerance, such as increased doses, progressive neglect of alternative pleasures or interest. Because of its psychological importance, caffeine withdrawal has been investigated in different studies. These studies demonstrated that the withdrawal starts $12-24 \mathrm{~h}$ after stopping caffeine intake and can last up to 9 days (122). People who take a minimum of $100 \mathrm{mg}$ caffeine per day can acquire a physical dependence that would trigger comparatively rather mild withdrawal symptoms that include muscle pain, stiffness, lethargy, nausea, vomiting, and depressed mood (122). The U.S. Food and Drug Administration (FDA) banned some pure caffeine powders and liquids in 2015 after deaths due to caffeine overdoses were reported. Recently, the FDA banned the sale of large tubs, containing dangerous amounts of caffeine in one package. One teaspoon of this coffee powder has the equivalent amount of caffeine as 28 cups of coffee ( $150 \mathrm{ml}$ coffee/cup) (123).

Over the last years, caffeine has also been investigated concerning Alzheimer's disease (AD) because of its potential effect as an antioxidant and by reducing oxidative stress. AD is defined as a progressive and irreversible neurodegenerative disease, which evolves into a disorder, concerning memory, cognition, and behavior. It is assumed that it affects $50 \%$ of people over the age of 80 years (124). A recent epidemiological study came to the results, that a long-term caffeine intake for more than 10 years decreases the risk of AD (125). Another 21-year followup study found an inverse association between coffee intake and the risk of developing $\mathrm{AD}$. A moderate consumption of coffee of 3 to 5 cups daily, significantly reduces the risk of AD (62-64\%) and dementia (65-70\%) in the later lifetime, compared to a lower consumption of 0 to 2 cups per day (126).

Also in animal models of $\mathrm{AD}$, effects of caffeine have been investigated. Chronic caffeine intake in APPsw mice had a protective effect on cognition and also reduced brain $ß$-amyloid production and deposits (127). Mice, which received $1,5 \mathrm{mg}$ caffeine per day for $4-5$ weeks which is equivalent to an intake of $500 \mathrm{mg} / \mathrm{d}$ caffeine (4-6 cups of coffee) showed a significant improvement in memory, compared to controls (128). These highly interesting results should also be examined more closely in future studies. 
Coffee and caffeine may reduce the risk of some neurodegenerative diseases significantly if contained in high doses. Still the mechanisms which are responsible for the beneficial effects are not completely understood so far. In all these neurodegenerative disorders it is assumed that besides dietary habits, also genetics and additional environmental factors may contribute. In future studies, the facet of the impact of coffee and caffeine that should be investigated more closely is their effects to possibly reduce severity of disease course and of various neurological symptoms.

\section{DATA AVAILABILITY STATEMENT}

All datasets analyzed for this study are included in the manuscript and the Supplementary Files.

\section{REFERENCES}

1. Ebers GC. Environmental factors and multiple sclerosis. Lancet Neurol. (2008) 7:268-77. doi: 10.1016/S1474-4422(08)70 $042-5$

2. Sawcer S, Hellenthal G, Pirinen M, Spencer CC, Patsopoulos NA, Moutsianas L, et al. Genetic risk and a primary role for cell-mediated immune mechanisms in multiple sclerosis. Nature (2011) 476:214-9. doi: 10.1038/nature10251

3. Lublin FD, Reingold SC, Cohen JA, Cutter GR, Sørensen PS, Thompson AJ, et al. Defining the clinical course of multiple sclerosis. Neurology (2014) 83:278-86. doi: 10.1212/WNL.0000000000000560

4. Popp RF, Fierlbeck AK, Knüttel H, König N, Rupprecht R, Weissert $\mathrm{R}$, et al. Daytime sleepiness versus fatigue in patients with multiple sclerosis: a systematic review on the epworth sleepiness scale as an assessment tool. Sleep Med Rev. (2017) 32:95-108. doi: 10.1016/j.smrv.2016. 03.004

5. Mills RJ, Young CA. A medical definition of fatigue in multiple sclerosis. QJM. (2008) 101:49-60. doi: 10.1093/qjmed/hcm122

6. Iriarte J, Subirá ML, Castro P. Modalities of fatigue in multiple sclerosis: correlation with clinical and biological factors. Mult Scler. (2000) 6:124-30. doi: 10.1191/135245800678827572

7. Fisk JD, Pontefract A, Ritvo PG, Archibald CJ, Murray TJ. The impact of fatigue on patients with multiple sclerosis. Can J Neurol Sci. (1994) 21:9-14. doi: 10.1017/S0317167100048691

8. Koziarska D, Król J, Nocon D, Kubaszewski P, Rzepa T, Nowacki P. Prevalence and factors leading to unemployment in MS (multiple sclerosis) patients undergoing immunomodulatory treatment in poland. PLoS ONE (2018) 13:e0194117. doi: 10.1371/journal.pone.0194117

9. Smith MM, Arnett PA. Factors related to employment status changes in individuals with multiple sclerosis. Mult Scler. (2005) 11:602-9. doi: 10.1191/1352458505ms1204oa

10. Hadjimichael O, Vollmer T, Oleen-Burkey M. Fatigue characteristics in multiple sclerosis: the north american research committee on multiple sclerosis (NARCOMS) survey. Health Qual Life Outcomes (2008) 6:100. doi: 10.1186/1477-7525-6-100

11. Krupp LB, LaRocca N, Muir-Nash J, Steinberg A. The fatigue severity scale: application to patients with multiple sclerosis ans systemic lupus erythematosus. Arch Neurol. (1989) 46:1121-3. doi: 10.1001/archneur.1989.00520460115022

12. Rocca M, Meani A, Riccitelli G, Colombo B, Rodegher M, Falini A, et al. Abnormal adaptation over time of motor network recruitment in multiple sclerosis patients with fatigue. Mult Scler. (2016) 22:1144-53. doi: $10.1177 / 1352458515614407$

13. Veauthier C, Paul F. Therapie der fatigue bei multipler sklerose ein behandlungsalgorithmus. Nervenarzt (2016) 87:1310-21. doi: 10.1007/s00115-016-0128-7

\section{AUTHOR CONTRIBUTIONS}

LH and RW outlined the subject of the review, searched for analyses, interpreted literature and wrote the manuscript. LH and RW agreed to be accountable for all aspects of the work.

\section{FUNDING}

The funding was provided by the University of Regensburg.

\section{SUPPLEMENTARY MATERIAL}

The Supplementary Material for this article can be found online at: https://www.frontiersin.org/articles/10.3389/fnut.2018. 00133/full\#supplementary-material

14. Lange R, Volkmer M, Heesen C, Liepert J. Modafinil effects in multiple sclerosis patients with fatigue. J Neurol. (2009) 256:645-50. doi: 10.1007/s00415-009-0152-7

15. Rosenberg GA, Appenzeller O. Amantadine, fatigue, and multiple sclerosis. Arch Neurol. (1988) 45:1104-6. doi: 10.1001/archneur.1988.00520340058012

16. Phyo AZ, Demaneuf T, Livera AM de, Jelinek GA, Brown CR, Marck CH, et al. The efficacy of psychological interventions for managing fatigue in people with multiple sclerosis: a systematic review and meta-analysis. Front Neurol. (2018) 9:149. doi: 10.3389/fneur.2018.00149

17. Krupp LB. Fatigue in multiple sclerosis: definition, pathophysiology and treatment. CNS drugs (2003) 17:225-34. doi: 10.2165/00023210-200317040-00002

18. Ferreira JJ, Mestre T, Guedes LC, Coelho M, Rosa MM, Santos AT, et al. Espresso coffee for the treatment of somnolence in parkinson's disease: results of n-of-1 trials. Front Neurol. (2016) 7 (Suppl. 3):455 doi: 10.3389/fneur.2016.00027

19. Exler A. Coca-Cola: Vom selbstgebrauten Aufputschmittel zur amerikanischen Ikone. Hamburg: Europäische Verlagsanstalt (2006). 92 p.

20. Kiple KF, Ornelas KC, editors. The Cambridge world history of food: Vol. 1. Cambridge: Cambridge University Press (2000). 1120 p.

21. Topik SC. Coffee. In: Kiple KF, Ornelas KC, editors. The Cambridge world history of food: Vol. 1. Cambridge: Cambridge University Press (2000). p. 641-53.

22. Pendergrast M. Uncommon grounds: The history of coffee and how it transformed our world. New York, NY: Basic Books (1999). XIX, 520 p.

23. Weinberg BA, Bealer BK. The world of caffeine: The science and culture of the world's most popular drug. New York, NY; London: Routledge (2002). 394 p.

24. Casal S, Oliveira MB, Alves MR, Ferreira MA. Discriminate analysis of roasted coffee varieties for trigonelline, nicotinic acid, and caffeine content. $J$ Agric Food Chem. (2000) 48:3420-4. doi: 10.1021/jf990702b

25. Tajik N, Tajik M, Mack I, Enck P. The potential effects of chlorogenic acid, the main phenolic components in coffee, on health: a comprehensive review of the literature. Eur J Nutr. (2017) 56:2215-44. doi: 10.1007/s00394-017-1379-1

26. Zhao Y, Wang J, Ballevre O, Luo H, Zhang W. Antihypertensive effects and mechanisms of chlorogenic acids. Hypertens Res. (2012) 35:370-4. doi: 10.1038/hr.2011.195

27. $\mathrm{Xu} \mathrm{J-G}, \mathrm{Hu} \mathrm{Q}-\mathrm{P}$, Liu Y. Antioxidant and DNA-protective activities of chlorogenic acid isomers. J Agric Food Chem. (2012) 60:11625-30. doi: $10.1021 /$ jf303771s

28. Martone PT, Estevez JM, Lu F, Ruel K, Denny MW, Somerville C, et al. Discovery of lignin in seaweed reveals convergent evolution of cell-wall architecture. Curr Biol. (2009) 19:169-75. doi: 10.1016/j.cub.2008.12.031

29. Farah A. Coffee Constituents. In: Chu Y-F, editor. Coffee: Emerging Health Effects and Disease Prevention. Oxford: Wiley-Blackwell (2012). p. 21-58.

30. Clarke RJ, Macrae R, editors. Coffee: Volume 2: Technology. Dordrecht: Springer (1987). $321 \mathrm{p}$. 
31. Speer K, Kölling-Speer I. The lipid fraction of the coffee bean. Braz J Plant Physiol. (2006) 18:201-16. doi: 10.1590/S1677-04202006000100014

32. Spiller MA. The chemical components of coffee. In: Spiller GA, editors. Caffeine, Boca Raton, FL: CRC Press (1998) 97-162.

33. Higdon JV, Frei B. Coffee and health: a review of recent human research. Crit Rev Food Sci Nutr. (2006) 46:101-23. doi: 10.1080/10408390500400009

34. Iwai K, Kishimoto N, Kakino $\mathrm{Y}$, Mochida K, Fujita T. In vitro antioxidative effects and tyrosinase inhibitory activities of seven hydroxycinnamoyl derivatives in green coffee beans. J Agric Food Chem. (2004) 52:4893-8. doi: 10.1021/jf040048m

35. Hameleers P. Habitual caffeine consumption and its relation to memory, attention, planning capacity and psychomotor performance across multiple age groups. Hum Pychopharmacol Clin Exp. (2000) 15:573-81. doi: 10.1002/hup.218

36. Fredholm BB, Bättig K, Holmén J, Nehlig A, Zvartau EE. Actions of caffeine in the brain with special reference to factors that contribute to its widespread use. Pharmacol Rev. (1999) 51:83-133.

37. Debry G, Nehlig A. Le café, source de performance ou de dépendance? Rev Infirm. (1994) 55-62.

38. Lieberman HR, Stavinoha TB, McGraw SM, White A, Hadden LS, Marriott BP. Use of dietary supplements among active-duty US army soldiers. Am J Clin Nutr. (2010) 92:985-95. doi: 10.3945/ajcn.2010.29274

39. McLellan TM, Lieberman HR. Do energy drinks contain active components other than caffeine? Nutr Rev. (2012) 70:730-44. doi: 10.1111/j.1753-4887.2012.00525.x

40. Barone JJ, Roberts HR. Caffeine consumption. Food Chem Toxicol. (1996) 34:119-29. doi: 10.1016/0278-6915(95)00093-3

41. Alharbi WD, Azmat A, Ahmed M. Comparative effect of coffee robusta and coffee arabica (qahwa) on memory and attention. Metab Brain Dis. (2018) 33:1203-10. doi: 10.1007/s11011-018-0230-6

42. Marks V, Kelly JF. Absorption of caffeine from tea, coffee and coca cola. Lancet (1973) 1:827. doi: 10.1016/S0140-6736(73)90625-9

43. Bonati M, Latini R, Galletti F, Young JF, Tognoni G, Garattini S. Caffeine disposition after oral doses. Clin Pharmacol Ther. (1982) 32:98-106. doi: 10.1038/clpt.1982.132

44. Blanchard J, Sawers SJ. The absolute bioavailability of caffeine in man. Eur J Clin Pharmacol. (1983) 24:93-8. doi: 10.1007/BF00613933

45. Fisone G, Borgkvist A, Usiello A. Caffeine as a psychomotor stimulant: mechanism of action. Cell Mol Life Sci. (2004) 61:857-72. doi: 10.1007/s00018-003-3269-3

46. Sheth S, Brito R, Mukherjea D, Rybak LP, Ramkumar V. Adenosine receptors: expression, function and regulation. Int J Mol Sci. (2014) 15:202452. doi: 10.3390/ijms15022024

47. McLellan TM, Caldwell JA, Lieberman HR. A review of caffeine's effects on cognitive, physical and occupational performance. Neurosci Biobehav Rev. (2016) 71:294-312. doi: 10.1016/j.neubiorev.2016.09.001

48. Kamp TJ, Hell JW. Regulation of cardiac L-type calcium channels by protein kinase A and protein kinase C. Circ Res. (2000) 87:1095-102. doi: 10.1161/01.RES.87.12.1095

49. Ribeiro JA, Sebastião AM. Caffeine and adenosine. J Alzheimers Dis. (2010) 20:S3-15. doi: 10.3233/JAD-2010-1379

50. Kolahdouzan M, Hamadeh MJ. The neuroprotective effects of caffeine in neurodegenerative diseases. CNS Neurosci Ther. (2017) 23:272-90. doi: $10.1111 / \mathrm{cns} .12684$

51. Jarvis MF, Williams M. Direct autoradiographic localization of adenosine A2 receptors in the rat brain using the A2-selective agonist, 3HCGS 21680. Eur J Pharmacol. (1989) 168:243-6. doi: 10.1016/0014-2999(89)90571-2

52. Fastbom J, Pazos A, Palacios JM. The distribution of adenosine A1 receptors and 5'-nucleotidase in the brain of some commonly used experimental animals. Neuroscience (1987) 22:813-26. doi: 10.1016/0306-4522(87)92961-7

53. Ferré S, Fredholm BB, Morelli M, Popoli P, Fuxe K. Adenosinedopamine receptor-receptor interactions as an integrative mechanism in the basal ganglia. Trends Neurosci. (1997) 20:482-7. doi: 10.1016/S0166-2236(97)01096-5

54. Dall'Igna OP, Porciúncula LO, Souza DO, Cunha RA, Lara DR. Neuroprotection by caffeine and adenosine $\mathrm{A} 2 \mathrm{~A}$ receptor blockade of $\beta$-amyloid neurotoxicity. Br J Pharmacol. (2003) 139:1571. doi: $10.1038 /$ sj.bjp. 0705400
55. Mohamed RA, Agha AM, Nassar NN. SCH58261 the selective adenosine $\mathrm{A}(2 \mathrm{~A})$ receptor blocker modulates ischemia reperfusion injury following bilateral carotid occlusion: role of inflammatory mediators. Neurochem Res. (2012) 37:538-47. doi: 10.1007/s11064-011-0640-x

56. Sonsalla PK, Wong L-Y, Harris SL, Richardson JR, Khobahy I, Li W, et al Delayed caffeine treatment prevents nigral dopamine neuron loss in a progressive rat model of Parkinson's disease. Exp Neurol. (2012) 234:482-7. doi: 10.1016/j.expneurol.2012.01.022

57. Tsutsui S, Schnermann J, Noorbakhsh F, Henry S, Yong VW, Winston BW, et al. A1 adenosine receptor upregulation and activation attenuates neuroinflammation and demyelination in a model of multiple sclerosis. Neurosci. (2004) 24:1521-9. doi: 10.1523/JNEUROSCI.4271-03.2004

58. Dobson KL, Jackson C, Balakrishnan S, Bellamy TC. Caffeine modulates vesicle release and recovery at cerebellar parallel fibre terminals, independently of calcium and cyclic AMP signalling. PLOS ONE (2015) 10:e0125974. doi: 10.1371/journal.pone.0125974

59. Daly JW. Caffeine analogs: biomedical impact. Cell Mol Life Sci. (2007) 64:2153-69. doi: 10.1007/s00018-007-7051-9

60. McPherson PS, Kim YK, Valdivia H, Knudson CM, Takekura $\mathrm{H}$, Franzini-Armstrong $\mathrm{C}$, et al. The brain ryanodine receptor: a caffeine-sensitive calcium release channel. Neuron (1991) 7:17-25. doi: 10.1016/0896-6273(91)90070-G

61. Endo M. Calcium release from the sarcoplasmic reticulum. Physiol Rev. (1977) 57:71-108. doi: 10.1152/physrev.1977.57.1.71

62. Cameron OG, Modell JG, Hariharan M. Caffeine and human cerebral blood flow: a positron emission tomography study. Life Sci. (1990) 47:1141-6. doi: 10.1016/0024-3205(90)90174-P

63. Cardinali D. Methylxanthines: possible mechanisms of action in brain Trends Pharmacol Sci. (1980) 1:405-7. doi: 10.1016/0165-6147(80)90064-4

64. Conlay LA, Conant JA, deBros F, Wurtman R. Caffeine alters plasma adenosine levels. Nature (1997) 389:136. doi: 10.1038/38160

65. Maughan RJ, Griffin J. Caffeine ingestion and fluid balance: a review. J Hum Nutr Diet. (2003) 16:411-20. doi: 10.1046/j.1365-277X.2003.00477.x

66. James JE. Critical review of dietary caffeine and blood pressure: a relationship that should be taken more seriously. Psychosom Med. (2004) 66:63-71. doi: 10.1097/10.PSY.0000107884.78247.F9

67. Lopez-Garcia E, van Dam RM, Willett WC, Rimm EB, Manson JE, Stampfer MJ, et al. Coffee consumption and coronary heart disease in men and women: a prospective cohort study. Circulation (2006) 113:2045-53. doi: 10.1161/CIRCULATIONAHA.105.598664

68. Steffen M, Kuhle C, Hensrud D, Erwin PJ, Murad MH. The effect of coffee consumption on blood pressure and the development of hypertension: a systematic review and meta-analysis. J Hypertens. (2012) 30:2245-54 doi: 10.1097/HJH.0b013e3283588d73

69. Nieber K. The impact of coffee on health. Planta Med. (2017) 83:1256-63. doi: 10.1055/s-0043-115007

70. Moher D, Shamseer L, Clarke M, Ghersi D, Liberati A, Petticrew $\mathrm{M}$, et al. Preferred reporting items for systematic review and metaanalysis protocols (PRISMA-P) 2015 statement. Syst Rev. (2015) 4:1. doi: 10.1186/2046-4053-4-1

71. Hedström AK, Mowry EM, Gianfrancesco MA, Shao X, Schaefer CA, Shen $\mathrm{L}$, et al. High consumption of coffee is associated with decreased multiple sclerosis risk; results from two independent studies. J Neurol Neurosurg Psychiatry (2016) 87:454-60. doi: 10.1136/jnnp-2015-312176

72. Massa J, O’Reilly EJ, Munger KL, Ascherio A. Caffeine and alcohol intakes have no association with risk of multiple sclerosis. Mult Scler. (2013) 19:53-8. doi: $10.1177 / 1352458512448108$

73. Ponsonby A-L, Lucas RM, Dear K, van der Mei I, Taylor B, Chapman $\mathrm{C}$, et al. The physical anthropometry, lifestyle habits and blood pressure of people presenting with a first clinical demyelinating event compared to controls: the ausimmune study. Mult Scler. (2013) 19:1717-25. doi: $10.1177 / 1352458513483887$

74. D’hooghe MB, Haentjens P, Nagels G, Keyser J. Alcohol, coffee, fish, smoking and disease progression in multiple sclerosis. Eur J Neurol. (2012) 19:616-24 doi: 10.1111/j.1468-1331.2011.03596.x

75. Pekmezovic T, Drulovic J, Milenkovic M, Jarebinski M, Stojsavljevic N, Mesaros S, et al. Lifestyle factors and multiple sclerosis: a case-control study in belgrade. Neuroepidemiology (2006) 27:212-6. doi: 10.1159/000096853 
76. Chen GQ, Chen YY, Wang XS, Wu SZ, Yang HM, Xu HQ, et al. Chronic caffeine treatment attenuates experimental autoimmune encephalomyelitis induced by guinea pig spinal cord homogenates in wistar rats. Brain Res. (2010) 1309:116-25. doi: 10.1016/j.brainres.2009.10.054

77. Cleveland DW, Rothstein JD. From charcot to lou gehrig: deciphering selective motor neuron death in ALS. Nat Rev Neurosci. (2001) 2:806-19. doi: $10.1038 / 35097565$

78. Fondell E, O’Reilly ÉJ, Fitzgerald KC, Falcone GJ, Kolonel LN, Park Y, et al. Intakes of caffeine, coffee and tea and risk of amyotrophic lateral sclerosis: results from five cohort studies. Amyotroph Lateral Scler Frontotemporal Degener. (2015) 16:366-71. doi: 10.3109/21678421.2015.1020813

79. Beghi E, Pupillo E, Messina P, Giussani G, Chiò A, Zoccolella S, et al. Coffee and amyotrophic lateral sclerosis: a possible preventive role. Am J Epidemiol. (2011) 174:1002-8. doi: 10.1093/aje/kwr229

80. Morozova N, Weisskopf MG, McCullough ML, Munger KL, Calle EE, Thun MJ, et al. Diet and amyotrophic lateral sclerosis. Epidemiology (2008) 19:324-37. doi: 10.1097/EDE.0b013e3181632c5d

81. Potenza RL, Armida M, Ferrante A, Pèzzola A, Matteucci A, Puopolo M, et al. Effects of chronic caffeine intake in a mouse model of amyotrophic lateral sclerosis. J Neurosci Res. (2013) 91:585-92. doi: 10.1002/jnr.23185

82. Noyce AJ, Bestwick JP, Silveira-Moriyama L, Hawkes CH, Giovannoni G, Lees AJ, et al. Meta-analysis of early nonmotor features and risk factors for Parkinson disease. Ann Neurol. (2012) 72:893-901. doi: 10.1002/ana.23687

83. Postuma RB. Caffeine for treatment of parkinson disease: a randomized controlled trial. Neurology (2012) 79:651-8. doi: 10.1212/WNL.0b013e318263570d

84. Postuma RB, Anang J, Pelletier A, Joseph L, Moscovich M, Grimes $D$, et al. Caffeine as symptomatic treatment for parkinson disease (Café-PD): a randomized trial. Neurology (2017) 89:1795-803. doi: 10.1212/WNL.0000000000004568

85. Simon DK, Swearingen CJ, Hauser RA, Trugman JM, Aminoff MJ, Singer C, et al. Caffeine and progression of parkinson disease. Clin Neuropharmacol. (2008) 31:189-96. doi: 10.1097/WNF.0b013e31815a3f03

86. Kitagawa M, Houzen H, Tashiro K. Effects of caffeine on the freezing of gait in Parkinson's disease. Mov Disord. (2007) 22:710-2. doi: 10.1002/mds.21208

87. Palacios N, Gao X, McCullough ML, Schwarzschild MA, Shah R, Gapstur S, et al. Caffeine and risk of parkinson's disease in a large cohort of men and women. Mov Disord. (2012) 27:1276-82. doi: 10.1002/mds.25076

88. Liu R, Guo X, Park Y, Huang X, Sinha R, Freedman ND, et al. Caffeine intake, smoking, and risk of parkinson disease in men and women. Am J Epidemiol. (2012) 175:1200-7. doi: 10.1093/aje/kwr451

89. Hu G, Bidel S, Jousilahti P, Antikainen R, Tuomilehto J. Coffee and tea consumption and the risk of Parkinson's disease. Mov Disord. (2007) 22:2242-8. doi: 10.1002/mds.21706

90. Sääksjärvi K, Knekt P, Rissanen H, Laaksonen MA, Reunanen A, Männistö S. Prospective study of coffee consumption and risk of Parkinson's disease in man and women. Eur J Clin Nutr. (2008) 62:908-15. doi: 10.1038/sj.ejcn.1602788

91. Ascherio A, Chen H, Schwarzschild MA, Zhang SM, Colditz GA, Speizer FE. Caffeine, postmenopausal estrogen, and risk of Parkinson's disease. Neurology (2003) 60:790-5. doi: 10.1212/01.WNL.0000046523.05125.87

92. Ascherio A, Weisskopf MG, O’Reilly EJ, McCullough ML, Calle EE, Rodriguez C, et al. Coffee consumption, gender, and Parkinson's disease mortality in the cancer prevention study II cohort: the modifying effects of estrogen. Am J Epidemiol. (2004) 160:977-84. doi: 10.1093/aje/kwh312

93. Ascherio A, Zhang SM, Hernán MA, Kawachi I, Colditz GA, Speizer FE, et al. Prospective study of caffeine consumption and risk of Parkinson's disease in men and women. Ann Neurol. (2001) 50:56-63. doi: 10.1002/ana.1052

94. Ross GW, Abbott RD, Petrovitch H, Morens DM, Grandinetti A, et al. Association of coffee and caffeine intake with the risk of Parkinson disease. JAMA (2000) 283:2674-9. doi: 10.1001/jama.283.20.2674

95. Hern T, Newton W. Does coffee protect against the development of Parkinson disease (PD)? J Fam Pract. (2000) 49:685-6.

96. Kumar PM, Paing SS, Li H, Pavanni R, Yuen Y, Zhao Y, et al. Differential effect of caffeine intake in subjects with genetic susceptibility to Parkinson's disease. Sci Rep. (2015) 5:15492. doi: 10.1038/srep 15492

97. van der Mark M, Nijssen PC, Vlaanderen J, Huss A, Mulleners WM, Sas $\mathrm{AM}$, et al. A case-control study of the protective effect of alcohol, coffee, and cigarette consumption on Parkinson disease risk: time-since-cessation modifies the effect of tobacco smoking. PLoS ONE (2014) 9:e95297. doi: 10.1371/journal.pone.0095297

98. Facheris MF, Schneider NK, Lesnick TG, Andrade M, Cunningham JM, Rocca WA, et al. Coffee, caffeine-related genes, and Parkinson's disease: a case-control study. Mov Disord. (2008) 23:2033-40. doi: 10.1002/mds.22247

99. Powers KM, Kay DM, Factor SA, Zabetian CP, Higgins DS, Samii A, et al. Combined effects of smoking, coffee, and NSAIDs on Parkinson's disease risk. Mov Disord. (2008) 23:88-95. doi: 10.1002/mds.21782

100. Hancock DB, Martin ER, Stajich JM, Jewett R, Stacy MA, Scott $\mathrm{BL}$, et al. Smoking, caffeine, and nonsteroidal anti-inflammatory drugs in families with Parkinson disease. Arch Neurol. (2007) 64:576-80. doi: 10.1001/archneur.64.4.576

101. Evans AH. Relationship between impulsive sensation seeking traits, smoking, alcohol and caffeine intake, and Parkinson's disease. J Neurol Neurosurg Psychiatry (2005) 77:317-21. doi: 10.1136/jnnp.2005.065417

102. Wirdefeldt K, Gatz M, Pawitan Y, Pedersen NL. Risk and protective factors for Parkinson's disease: a study in swedish twins. Ann Neurol. (2005) 57:2733. doi: 10.1002/ana.20307

103. Tan E-K, Tan C, Fook-Chong SMC, Lum SY, Chai A, Chung H, et al Dose-dependent protective effect of coffee, tea, and smoking in Parkinson's disease: a study in ethnic chinese. J Neurol Sci. (2003) 216:163-7. doi: 10.1016/j.jns.2003.07.006

104. Ragonese P, Salemi G, Morgante L, Aridon P, Epifanio A, Buffa D, et al. A case-control study on cigarette, alcohol, and coffee consumption preceding Parkinson's disease. Neuroepidemiology (2003) 22:297-304. doi: 10.1159/000071193

105. Checkoway H, Powers K, Smith-Weller T, Franklin GM, Longstreth WT, Swanson PD. Parkinson's disease risks associated with cigarette smoking, alcohol consumption, and caffeine intake. Am J Epidemiol. (2002) 155:732-8. doi: 10.1093/aje/155.8.732

106. Paganini-Hill A. Risk factors for parkinson's disease: the leisure world cohort study. Neuroepidemiology (2001) 20:118-24. doi: 10.1159/0000 54770

107. Benedetti MD, Bower JH, Maraganore DM, McDonnell SK, Peterson BJ, Ahlskog JE, et al. Smoking, alcohol, and coffee consumptioon preceding Parkinson's disease: a case-control study. Neurology (2000) 55:1350-8. doi: 10.1212/WNL.55.9.1350

108. Preux PM. Parkinson's disease and environmental factors: matched casecontrol study in the limousin region, France. Neuroepidemiology (2000) 19:333-7. doi: 10.1159/000026273

109. Fall P-A, Fredrikson M, Axelson O, Granérus A-K. Nutritional and occupational factors influencing the risk of Parkinson's disease: a casecontrol study in southeastern Sweden. Mov Disord. (1999) 14:28-37. doi: 10.1002/1531-8257(199901)14:1\&lt;28::AID-MDS1007\&gt;3.0.CO;2-O

110. Hellenbrand W, Seidler A, Boeing H, Robra BP, Vieregge P, Nischan P, et al. Diet and Parkinson's disease. I: a possible role for the past intake of specific foods and food groups. results from a self-administered foodfrequency questionnaire in a case-control study. Neurology (1996) 47:636-43. doi: 10.1212/WNL.47.3.636

111. Morano A, Jiménez-Jiménez FJ, Molina JA, Antolín MA. Risk-factors for Parkinson's disease: case-control study in the province of Cáceres, Spain. Acta Neurol Scand. (1994) 89:164-70. doi: 10.1111/j.1600-0404.1994.tb01655.x

112. Kandinov B, Giladi N, Korczyn AD. Smoking and tea consumption delay onset of Parkinson's disease. Parkinsonism Relat Disord. (2009) 15:41-6. doi: 10.1016/j.parkreldis.2008.02.011

113. Eriksen JL, Wszolek Z, Petrucelli L. Molecular pathogenesis of Parkinson disease. Arch Neurol. (2005) 62:353-7. doi: 10.1001/archneur.62. 3.353

114. Chen J-F, Xu K, Petzer JP, Staal R, Xu Y-H, Beilstein M, et al Neuroprotection by caffeine and A $2 \mathrm{~A}$ adenosine receptor inactivation in a model of Parkinson's disease. J Neurosci. (2001) 21:RC143. doi: 10.1523/JNEUROSCI.21-10-j0001.2001

115. Jenner P, Rupniak NM, Rose S, Kelly E, Kilpatrick G, Lees A, et al. 1-Methyl-4-phenyl-1,2,3,6-tetrahydropyridine-induced parkinsonism in the common marmoset. Neurosci Lett. (1984) 50:85-90. doi: 10.1016/0304-3940(84)90467-1 
116. Xu K, Xu Y, Brown-Jermyn D, Chen J-F, Ascherio A, Dluzen DE, et al. Estrogen prevents neuroprotection by caffeine in the mouse 1-methyl-4phenyl-1,2,3,6-tetrahydropyridine model of Parkinson's disease. J Neurosci. (2006) 26:535-41. doi: 10.1523/JNEUROSCI.3008-05.2006

117. Bagga P, Chugani AN, Patel AB. Neuroprotective effects of caffeine in MPTP model of Parkinson's disease: a (13)C NMR study. Neurochem Int. (2016) 92:25-34. doi: 10.1016/j.neuint.2015.11.006

118. Joghataie MT, Roghani M, Negahdar F, Hashemi L. Protective effect of caffeine against neurodegeneration in a model of Parkinson's disease in rat: behavioral and histochemical evidence. Parkinsonism Relat Disord. (2004) 10:465-8. doi: 10.1016/j.parkreldis.2004.06.004

119. Ungerstedt U. 6-hydroxy-dopamine induced degeneration of central monoamine neurons. Eur J Pharmacol. (1968) 5:107-10. doi: 10.1016/0014-2999(68)90164-7

120. Nakaso K, Ito S, Nakashima K. Caffeine activates the PI3K/Akt pathway and prevents apoptotic cell death in a Parkinson's disease model of SH-SY5Y cells. Neurosci Lett. (2008) 432:146-50. doi: 10.1016/j.neulet.2007.12.034

121. Jha SK, Jha NK, Kar R, Ambasta RK, Kumar P. p38 MAPK and PI3K/AKT signalling cascades in Parkinson's disease. Int J Mol Cell Med. (2015) 4:67-86.

122. Juliano LM, Griffiths RR. A critical review of caffeine withdrawal: empirical validation of symptoms and signs, incidence, severity, and associated features. Psychopharmacology (2004) 176:1-29. doi: $10.1007 / \mathrm{s} 00213-004-2000-\mathrm{x}$

123. LaVito A. FDA bans some pure caffeine powders and liquids that pack a potentially lethal punch (2018). Available online at: https://www.cnbc. com/2018/04/13/fda-bans-some-pure-caffeine-powders-and-liquids.html (Accessed 2018 Jun, 28).
124. Wyka J. Czynniki zywieniowe $\mathrm{w}$ zapobieganiu chorobie alzheimera. Rocz Panstw Zakl Hig. (2012) 63:135-40.

125. Maia L, Mendonca A. Does caffeine intake protect from Alzheimer's disease? Eur J Neurol. (2002) 9:377-82. doi: 10.1046/j.1468-1331.2002.00421.x

126. Eskelinen $\mathrm{MH}$, Ngandu T, Tuomilehto J, Soininen H, Kivipelto M. Midlife coffee and tea drinking and the risk of late-life dementia: a population-based CAIDE study. J Alzheimers Dis. (2009) 16:85-91. doi: 10.3233/JAD-2009-0920

127. Arendash GW, Schleif W, Rezai-Zadeh K, Jackson EK, Zacharia LC, Cracchiolo JR, et al. Caffeine protects Alzheimer's mice against cognitive impairment and reduces brain beta-amyloid production. Neuroscience (2006) 142:941-52. doi: 10.1016/j.neuroscience.2006.07.021

128. Arendash GW, Mori T, Cao C, Mamcarz M, Runfeldt M, Dickson A, et al. Caffeine reverses cognitive impairment and decreases brain amyloid-beta levels in aged Alzheimer's disease mice. J Alzheimers Dis. (2009) 17:661-80. doi: 10.3233/JAD-2009-1087

Conflict of Interest Statement: The authors declare that the research was conducted in the absence of any commercial or financial relationships that could be construed as a potential conflict of interest.

Copyright $\odot 2018$ Herden and Weissert. This is an open-access article distributed under the terms of the Creative Commons Attribution License (CC BY). The use, distribution or reproduction in other forums is permitted, provided the original author(s) and the copyright owner(s) are credited and that the original publication in this journal is cited, in accordance with accepted academic practice. No use, distribution or reproduction is permitted which does not comply with these terms. 